\title{
Association Between Hip-Waist Ratio and Physical Performance in Older Adults
}

\author{
Geraldine A. Espinoza Gutierrez ${ }^{1}$ (D) , Gabriela Yance-Cacñahuaray ${ }^{1}$ (D), Fernando M. Runzer-Colmenares ${ }^{1^{\star}}$ (D), \\ Diego Chambergo-Michilot ${ }^{1}$ (D), Ian Falvy-Bockos ${ }^{2}$ (D), Luis F. Vidal-Neira ${ }^{3}$ (D)
}

\author{
${ }^{1}$ Universidad Cientifica del Sur, Lima, PERU \\ ${ }^{2}$ Hospital Central Geriatrico de la FAP, Lima, PERU \\ ${ }^{3}$ Centro de Diagnóstico de Osteoporosis y Enfermedades Reumáticas (CEDOR), Lima, PERU \\ *Corresponding Author: frunzer@cientifica.edu.pe
}

Citation: Gutierrez GE, Yance-Cacñahuaray G, Runzer-Colmenares FM, Chambergo-Michilot D, Falvy-Bockos I, Vidal-Neira LF. Association Between Hip-Waist Ratio and Physical Performance in Older Adults. Electron J Gen Med. 2022;19(2):em355. https://doi.org/10.29333/ejgm/11566

\section{ARTICLE INFO}

Received: 15 Sep. 2021

Accepted: 24 Nov. 2021

\section{ABSTRACT} \\ Introduction: The aim of this study was to determine the association between the hip-waist ratio (WHR) and \\ physical performance (PP) in older adults.
}

Materials and Methods: A retrospective analytical design was carried out using the database of the study "Validation of the measure of grip strength with digital dynamometry in older adults".

Results: The participants included 84 older adults, with a mean age of $78.06 \pm 8.40$ years with a predominance of female sex (60.71\%; $n=51)$. PP was evaluated with the Short Physical Performance Battery, with most of the participants (67.86\%; $n=57)$ presenting adequate PP, and $47.62 \%(n=40)$ had a body mass index within normal parameters. The mean WHR was $0.94 \mathrm{~cm} . \pm 0.08$. The WHR was altered in $78.95 \%(n=45)$ and was normal in $21.05 \%$ $(n=12)$ of patients with adequate PP, while in participants with altered PP, $22.22 \%(n=6)$ had a normal WHR and $77.78 \%(n=21)$ had an altered WHR.

Discussion: These results suggest that WHR and PP are not associated. However, we found a significant relationship between WHR and PP in older women and older adults between 60 and 70 years of age.

Keywords: frail older adults, waist-hip ratio, physical functional performance

\section{INTRODUCTION}

In recent decades, the accelerated growth rate of the elderly population (EP) has had a global impact. Currently, it is estimated that this number will double by 2025 [1], causing a demographic transition to aging. Nutritional disorder usually impair the quality of life of the elderly [2] and can affect physical performance (PP) causing frailty and disability in this population.

Factors for adequate PP include good nutritional status (NS), physical activity, and adequate sleep patterns [3]. A way to assess nutritional status is with the use of anthropometric measurements, and one of the most widely used is the body mass index (BMI). However, in the last decades, its usefulness to describe the distribution of body fat mass in the EP has been questioned due to variation in its distribution during aging [4].

It was found that older patients with overweight and obesity presented greater PP [5]. This problem has led to the search for new alternatives such as the waist-hip ratio (WHR), which has shown to have a strong predictive value for metabolic syndrome being even better than BMI in the EP [6-8].

Studying the consequences of excess adipose tissue on PP is relevant since several studies have reported that excess weight can provide survival benefits in older adults [4]. In addition, there is controversy regarding the ideal body weight in the elderly. Many risk factors have already been identified that can affect PP in the EP. However, compared to the BMI there are few studies on the hip-waist ratio (WHR) and its relationship with PP in this population, despite the WHR having been identified as a significant risk factor for physical frailty [9]. The main objective of the present study was to determine the association between the WHR and PP in older adults treated in out-patient department of a military hospital.

\section{METHODS}

\section{Study Population}

An observational retrospective analytical study was performed, analyzing the database of the study "Validation of the measure of grip strength with digital dynamometry in older adults which was performed in retired Peruvian military personnel and relatives $\geq 60$ years treated in a military hospital from January-December 2019. The original data collection study included 97 subjects and the exclusion criteria were clock test score less than 7 [10], disability according to the criteria of [11], and the presence of congenital bone malformations, musculoskeletal or collagen diseases that may alter the results of muscle performance tests. The main objective of the original 
study was to correlate the measurement of muscle strength, using different dynamometers, and the chair-stand test. For the present study, the whole dataset of the participants in the original study who had complete information for the main variables were included, and those with incomplete information were excluded: WHR and Short Physical Performance Battery (SPPB). The final sample size consisted of 84 participants.

Measurement of the WHR was obtained by dividing the waist circumference (measured at the level of the last floating rib), by the maximum hip circumference in $\mathrm{cm}$ considering normal values as 0.71-0.85 for women and 0.78-0.94 for men [12].

Measurement of PP was evaluated using the SPPB [13], which consists of three tests: gait speed, measured in four meters; the chair-stand test, measured in seconds in which the participant must get up and sit on a chair five times in a row without leaning, and finally balance, which was evaluated in three positions like with the feet together, semi-tandem, and tandem. A score of less than or equal to eight was considered poor PP according to the European Working Group on Sarcopenia in Older People (EWGSOP) [14].

Anthropometric measurements included weight expressed in $\mathrm{kg}$, height measured in $\mathrm{cm}$ using a stadiometer with the participant standing; abdominal circumference determined at the level of the navel; the BMI calculated by dividing the weight in $\mathrm{kg}$ by the height expressed in $\mathrm{m}^{2}$; calf circumference, obtained by measuring the perimeter of the thickest part between the knee and the ankle of the patient in $\mathrm{cm}$ considering low muscle volume as a calf circumference of less than $31 \mathrm{~cm}$ according to the Mini Nutritional Assessment [15]; and lastly, muscle strength expressed in $\mathrm{kg}$ and evaluated using a hydraulic dynamometer (Jamar $\left.{ }^{\circledR}\right)$. A diagnosis of sarcopenia was considered when muscle strength was less than $27 \mathrm{~kg}$ in men and less than $16 \mathrm{~kg}$ in women as proposed by the EWGSOP2 [16].

Data of the clinical and sociodemographic characteristics consisted of age expressed in years; sex, marital status, categorized as single, married, divorced, or widowed; and the level of education, categorized according to the last period of studies completed: primary school, high school, technical college, university or no studies.

\section{Statistical Analysis}

The OpenEpi v3.0 program was used to calculate the sample size of the original study, in which the difference in muscle strength means $(\mathrm{kg})$ was evaluated by two dynamometers, one hydraulic and the other digital, assuming a difference of $1.5 \mathrm{~kg}$ and $2.1 \mathrm{~kg}$ in males and females, respectively. A total of 84 participants were needed for the study with a $95 \%$ confidence interval $(95 \% \mathrm{Cl})$, assuming a percentage of patients with altered PP and obesity of $66 \%$ [17] and $17 \%$ of altered SPPB in the general population [18], the statistical power was $85.21 \%$.

For the descriptive analysis of the sample we calculated frequencies, percentages, means, and standard deviations for the principal variables for the study. Additionally, we performed a bivariate analysis using the Student's t-test or ANOVA for numerical variables and the Fisher test for categorical variables. A p-value $<0.05$ and a $95 \% \mathrm{Cl}$ was considered as statistically significant. The statistical analyses were performing using STATA v15.0.
Table 1. Descriptive analysis of the study sample $(\mathrm{N}=84)$

\begin{tabular}{|c|c|c|c|}
\hline & $\mathbf{n}$ & $\%$ & Mean \pm SD \\
\hline \multicolumn{4}{|l|}{ Sex } \\
\hline Female & 51 & 60.71 & \\
\hline Male & 33 & 39.29 & \\
\hline Age & & & $78.06 \pm 8.40$ \\
\hline \multicolumn{4}{|l|}{ Marital status } \\
\hline Single & 1 & 1.19 & \\
\hline Married & 61 & 72.62 & \\
\hline Widower & 21 & 25 & \\
\hline Divorced & 1 & 1.19 & \\
\hline \multicolumn{4}{|l|}{ Education } \\
\hline Incomplete secondary & 3 & 3.57 & \\
\hline Completed secondary & 35 & 41.67 & \\
\hline Advanced technician & 21 & 25 & \\
\hline University superior & 25 & 29.76 & \\
\hline \multicolumn{4}{|l|}{ Sedentary lifestyle } \\
\hline Absence & 60 & 71.43 & \\
\hline Presence & 24 & 28.57 & \\
\hline Comorbidity & & & $1.37 \pm 1.17$ \\
\hline \multicolumn{4}{|l|}{ Body mass index } \\
\hline Normal & 40 & 47.62 & \\
\hline Overweight & 28 & 33.33 & \\
\hline Obese & 16 & 19.5 & \\
\hline \multicolumn{4}{|l|}{ Physical performance } \\
\hline Suitable & 57 & 67.86 & \\
\hline Poor & 27 & 32.14 & \\
\hline Waist-hip ratio & & & $0.94 \pm 0.08$ \\
\hline \multicolumn{4}{|l|}{ Waist-hip ratio by sex } \\
\hline Female & 18 & 21.43 & \\
\hline Male & 66 & 78.57 & \\
\hline
\end{tabular}

SD: Standard deviation

\section{Ethical Standards}

This work was approved by the Ethics Committee of the Scientific University of the South (code: 023-2018-PRO99). All the information collected from the participants was registered under strict confidentiality.

\section{RESULTS}

The present research was carried out with the data of 84 participants from the Geriatric Department of the Central Hospital FAP. A descriptive analysis of the sociodemographic characteristics (age, sex, marital status, and education), comorbidities, sedentary lifestyle, and anthropometric measures (BMI, WHR, and WHR/sex) of the study sample was performed (Table 1). The mean age of the participants was $78.06 \pm 8.40$ years, with a predominance of female sex of $60.71 \%$ $(n=51)$. Most of the elderly were married $(72.62 \% ; n=61)$ and had a high school education (41.67\%; $n=35)$, and only $28.57 \%$ $(n=24)$ presented sedentarism. In addition, a mean of $1.37 \pm 1.17$ had comorbidities and the mean WHR was $0.94 \mathrm{~cm} \pm 0.08$. According to the SPPB, $67.86 \%(n=57)$ had adequate PP, and the BMI was within normal parameters in $47.62 \%$ of the participants $(n=40)$. In the bivariate analysis (Table 2 ), the WHR was altered in $78.95 \%(n=45)$ and was normal in $21.05 \%(n=12)$ of patients with adequate $\mathrm{PP}$, while in participants with altered PP, $22.22 \%(n=6)$ had a normal WHR and $77.78 \%(n=21)$ had an altered WHR, with no association according to the known cutoff points known for sex and PP. However, when adjusting for sex and age, the values were statistically significant only in women and older adults between 60 and 70 years of age. 
Table 2. Bivariate analysis of physical performance, the waist-hip ratio, and covariates $(\mathrm{N}=84)$

\begin{tabular}{|c|c|c|c|}
\hline Variables & Adequate physical performance & Altered physical performance & p-value \\
\hline Waist-hip ratio & & & 0.6 \\
\hline Normal & $12(21.05)$ & $6(22.22)$ & \\
\hline Altered & $45(78.95)$ & $21(77.78)$ & \\
\hline \multicolumn{4}{|c|}{ Mean waist-to-hip ratio (standard deviation) } \\
\hline In women & $0.93(0.07)$ & $0.89(0.06)$ & 0.05 \\
\hline In men & $0.96(0.05)$ & $0.99(0.12)$ & 0.3 \\
\hline \multicolumn{4}{|l|}{ Body mass index } \\
\hline Normal: $<25$ & $0.94(0.08)$ & $0.90(0.06)$ & 0.16 \\
\hline Overweight: >25 & $0.96(0.04)$ & $0.02(0.07)$ & 0.18 \\
\hline Obese: $>30$ & $0.94(0.04)$ & $1.05(0.10)$ & 0.25 \\
\hline \multicolumn{4}{|l|}{ Age } \\
\hline $60-70$ & $0.94(0.05)$ & $0.99(0.16)$ & 0.41 \\
\hline $71-80$ & $0.92(0.06)$ & $0.90(0.04)$ & 0.23 \\
\hline$\geq 81$ & $0.97(0.06)$ & $0.93(0.71)$ & 0.12 \\
\hline \multicolumn{4}{|l|}{ Sedentary lifestyle } \\
\hline Absence & $0.94(0.71)$ & $0.92(0.063)$ & 0.28 \\
\hline Presence & $0.97(0.04)$ & $0.97(0.15)$ & 0.81 \\
\hline
\end{tabular}

Likewise, when adjusting for the BMI, it was found that the higher the BMI, the worse the PP.

\section{DISCUSSION}

The main objective of the study was to determine the association between the WHR and PP in military elderly participants, with no statistically significant association being found between the two variables. However, adjustment for gender and age showed statistically significant associations. These findings agree with the study [19] in which the WHR and waist circumference were not associated with PP compared to other anthropometric variables in a sample including $68.1 \%$ of women $(n=420)$.

Changes in NS are directly related to physical body changes, the monitoring of which is done through the use of anthropometric measurements [19]. The BMI is one of the measurements most used and at the same time it is one of the most questioned in the elderly due to the variation in the distribution of adipose tissue which occurs with aging. An alternative to anthropometric measurements in this population is the WHR. In the bivariate analysis by gender, only women who had a higher or altered WHR presented an adequate PP, contrary to what would be expected. However, according to the literature, subjects with high-fat masses tend to have a greater lean mass, and this is associated with a lower risk of incident disability [20]; nonetheless, these results are only significant in older adult women [20,21].

Similarly, in the bivariate analysis, women with a lower or normal WHR had an altered PP. In a study [22] including more than 2,000 older adult participants, it was found that only in women, with or without comorbidities, lower anthropometric indices were associated with higher mortality and disability. These results could therefore be extrapolated to the present study in which the sample was mostly female and with a mean number of comorbidities of $1.37 \pm 1.17$, which could explain the association between a low WHR, poor PP, and female sex. Likewise, it is known that at older ages there is a correlation with the increase in adipose tissue; however, this only occurs from 55 to 65 years old, especially in women [22]. Thus, the relationship between PP and the WHR could behave as an inverted U-curve, with both high and low WHR values being associated with poorer PP.
The most relevant results in most studies in older adults that report these paradoxical or controversial results are that they tend to be found in a predominantly female population since they tend to have different results in terms of BMI and WHR. The reason for these different results may be correlated with sociodemographic characteristics; for example, in European women, abdominal obesity (measured as the WHR) is strongly related to the BMI [23]. On the other hand, in Asian women, both the WHR and the conicity index are independent of the BMI [23]. These findings are complemented in a study performed in Finland [20] in which four anthropometric variables (BMI, waist circumference, fat mass, and percentage of body fat) with above normal ranges were directly related to a worse PP in both sexes.

Along the same lines, when anthropometric measures such as calf, hip, waist circumference, or BMI are used, the amount of muscle mass could explain the variability of the results in participants of the same age and sex with similar anthropometric characteristics [24]. In the National Health and Nutrition Examination Survey database [20] a lower lean mass was associated with a higher risk of physical disability in older adults, which is logical since it is related to the definition of sarcopenia. However, an inverse relationship in which a heightadjusted low lean mass showed adequate PP in adult participants over 70 years of age [25]. These contrasting results show the challenge of using these isolated anthropometric measurements without assessing muscle mass.

Regarding the variable of age, a longitudinal study reported that older adult patients with a higher percentage of body fat showed a reduction in resistance in a 400-meter walk [26]. However, no significant associations were found among participants aged 70 to 79 years, these results are consistent with those of our study, in which on adjustment for age, it was found that the higher the WHR, the worse the PP.

The present study has certain limitations. The results were obtained from a database of a Peruvian military outpatient hospital population, and therefore, conclusions could not be extrapolated to other populations of older adults. However, this sample is representative of a population of older adults belonging to the armed forces and the findings are relevant in the field of comprehensive geriatric evaluation concerning functional and nutritional domains. 
In conclusion, the results of this study suggest that the WHR and PP are not associated in this military outpatient hospital population. However, only women who had a higher or altered WHR and older adults between 60 and 70 years old presented an adequate PP, contrary to what would be expected. More longitudinal studies are needed to compare PP according to different anthropometric measures such as sex and age, due to the contradictory results described in the medical literature to date.

Author contributions: All authors have sufficiently contributed to the study, and agreed with the results and conclusions.

Funding: The original study was funded by a grant from the Peruvian American Medical Society (PAMS), obtained through an international competition organized by this society.

Declaration of interest: No conflict of interest is declared by authors.

\section{REFERENCES}

1. Tarqui-Mamani C, Alvarez-Dongo D, Espinoza-Oriundo $P$, Gomez-Guizado G. Estado nutricional asociado a características sociodemográficas en el adulto mayor Peruano [Nutritional status associated with sociodemographic characteristics in the Peruvian elderly]. Rev Peru Med Exp Salud Publica. 2014;31(3):467-72. https://doi.org/10.17843/rpmesp.2014.313.82 PMid:25418644

2. Guede FA, Chirosa LJ, Fuentealba SA, et al. Características antropométricas y condición física funcional de adultos mayores Chilenos insertos en la comunidad [Anthropometric characteristics and functional physical condition of Chilean older adults inserted in the community]. Nutr Hosp. 2017;34(6). https://doi.org/ 10.20960/nh. 1288

3. Hutasuhut F, Ryoto V. Associations between muscle grip strength with age, body mass index, waist-to-hip ratio, level of independent, physical activity level and macronutrient intake in elderly women. Pakistan J Nutr. 2014;13(7):409-14. https://doi.org/10.3923/pjn.2014.409. 414

4. Lisko I, Stenholm S, Raitanen J, et al. Association of body mass index and waist circumference with physical functioning: the vitality $90+$ study. J Gerontol A Biol Sci Med Sci. 2005;70(7):885-91. https://doi.org/10.1093/gerona/ glu202 PMid:25394617

5. De Stefano F, Zambon S, Giacometti L, et al. Obesity, muscular strength, muscle composition and physical performance in an elderly population. J Nutr Health Aging. 2015;19(7):785-91. https://doi.org/10.1007/s12603-0150482-3 PMid:26193864

6. Dalton M, Cameron AJ, Zimmet PZ, et al. Waist circumference, waist-hip ratio and body mass index and their correlation with cardiovascular disease risk factors in Australian adults. J Intern Med. 2003;25(6):555-63. https://doi.org/10.1111/j.1365-2796.2003.01229.x PMid: 14641796

7. Fauziana R, Jeyagurunathan A, Abdin E, et al. Body mass index, waist-hip ratio and risk of chronic medical condition in the elderly population: results from the well-being of the Singapore elderly (WiSE) study. BMC Geriatr. 2016;16:125. https://doi.org/10.1186/s12877-016-0297-z PMid:27315800 PMCid:PMC4912714
8. Kawamoto R, Kikuchi A, Akase T, Ninomiya, D, Kumagi T. Usefulness of waist-to-height ratio in screening incident metabolic syndrome among Japanese communitydwelling elderly individuals. PLoS One. 2019;14(4): e0216069. https://doi.org/10.1371/journal.pone.0216069 PMid:31034487 PMCid:PMC6488078

9. Serra-Prat, M, Papiol M, Vico J, Palomera E, Arus M, Cabre $M$. Incidence and risk factors for frailty in the communitydwelling elderly population. A two-year follow-up cohort study. J Gerontol Geriatr Res. 2017;6(6):452. https://doi.org/10.4172/2167-7182.1000452

10. Custodio N, García A, Montesinos R, Lira D, Bendezu L. Validación de la prueba de dibujo del reloj-versión de manos - como prueba de cribado para detectar demencia en una población adulta mayor de Lima, Perú [Validation of the clock-hand version drawing test - as a screening test to detect dementia in an older adult population of Lima, Peru]. Rev Peru Med Exp Salud Publica. 2011;28(1):29-34. https://doi.org/10.17843/rpmesp.2011.281.452

PMid:21537766

11. Dinamarca-Montecinos JL. Dismovilidad en geriatría: una década definiendo un concepto clínico [Dysmobility in geriatrics: a decade defining a clinical concept]. Bol Hosp Viña Mar. 2012;68(2):15-9.

12. Lean ME, Han TS, Morrison CE. Waist circumference as a measure for indicating need for weight management. BMJ. 1995;311(6998):158-61. https://doi.org/10.1136/bmj.311. 6998.158 PMid:7613427 PMCid:PMC2550221

13. Guralnik JM, Simonsick EM, Ferrucci L, et al. A short physical performance battery assessing lower extremity function: association with self-reported disability and prediction of mortality and nursing home admission. J Gerontol. 1994;49(2):M85-94. https://doi.org/10.1093/ geronj/49.2.M85 PMid:8126356

14. Cruz-Jentoft, AJ, Bahat G, Bauer J, et al. Sarcopenia: revised European consensus on definition and diagnosis. Age Ageing. 2019;48(1):16-31. https://doi.org/10.1093/ ageing/afy169 PMid:30312372 PMCid:PMC6322506

15. Kaiser MJ, Bauer JM, Ramsch C, et al. Validation of the mini nutritional assessment short-form (MNA-SF): a practical tool for identification of nutritional status. J Nutr Health Aging. 2009;13(9):782-8. https://doi.org/10.1007/s12603009-0214-7 PMid:19812868

16. Viktil KV, Blix HS, Moger TA, Reikvam A. Polypharmacy as commonly defined is an indicator of limited value in the assessment of drug - related problems. $\mathrm{Br} \mathrm{J}$ Clin Pharmacol. 2007;63(2):187-95. https://doi.org/10.1111/j.13 65-2125.2006.02744.x PMid:16939529 PMCid:PMC2000563

17. Volpato S, Cavalieri M, Sioulis F, et al. Predictive value of the short physical performance battery following hospitalization in older patients. J Gerontol A Biol Sci Med Sci. 2011;66(1):89-96. https://doi.org/10.1093/gerona/ glq167 PMid:20861145 PMCid:PMC3011958

18. Kim YH, Kim K-I, Paik N-J, Kim K-W, Jang HC, Lim J-Y. Muscle strength: a better index of low physical performance than muscle mass in older adults. Geriatr Gerontol Int. 2016;16(5):577-85. https://doi.org/10.1111/ ggi.12514 PMid:26017097 
19. Silva NA, Pedraza DF, Menezes TN. Desempenho funcional e sua associação com variáveis antropométricas e de composição corporal em idosos [Functional performance and its association with anthropometric and body composition variables in the elderly]. Cien Saude Colet. 2015;20(12):3723-32. https://doi.org/10.1590/1413-812320 152012.01822015 PMid:26691797

20. Mikkola TM, von Bonsdorff MB, Salonen MK, et al. Body composition as a predictor of physical performance in older age: a ten-year follow-up of the Helsinki birth cohort study. Arch Gerontol Geriatr. 2018;77:163-8. https://doi. org/10.1016/j.archger.2018.05.009 PMid:29783137 PMCid: PMC5994345

21. Cesari M, Rolland Y, Abellan Van Kan G, et al. Sarcopeniarelated parameters and incident disability in older persons: results from the "invecchiare in Chianti" study. J Gerontol A Biol Sci Med Sci. 2015;70(4):457-63. https://doi.org/10. 1093/gerona/glu181 PMid:25320055 PMCid:PMC4375415

22. Woo J, Ho SC, Sham A. Longitudinal changes in body mass index and body composition over 3 years and relationship to health outcomes in Hong Kong Chinese age 70 and older. J Am Geriatr Soc. 2001;49(6):737-46. https://doi.org/ 10.1046/j.1532-5415.2001.49150.x PMid:11454112
23. Kusuma YS, Babu BV, Naidu JM. Chronic energy deficiency in some low socio-economic populations from South India: relationships between body mass index, waist-hip ratio and conicity index. Homo. 2008;59(1):67-79. https://doi.org /10.1016/j.jchb.2006.10.006 PMid:17675005

24. Holguera RM, Nieves AIT, Torres RR, Alonso MC. Asociación de la masa muscular determinada mediante DEXA con los resultados espirométricos de individuos sanos [Association of the muscle mass determined by DEXA with the spirometric results of healthy individuals]. Arch Bronconeumol. 2017;53(7):375-80. https://doi.org/10.1016 /j.arbres.2016.11.020 PMid:28108044

25. Delmonico MJ, Harris TB, Lee J-S, et al. Alternative definitions of sarcopenia, lower extremity performance, and functional impairment with aging in older men and women. J Am Geriatr Soc. 2007;55(5):769-74. https://doi. org/10.1111/j.1532-5415.2007.01140.x PMid:17493199

26. Jerome GJ, Ko S-U, Shaffer NSC, Studenski SA, Ferrucci L, Simonsick EM. Cross-sectional and longitudinal associations between adiposity and walking endurance in adults age 60-79. J Gerontol A Biol Sci Med Sci. 2016; 71(12):1661-6. https://doi.org/10.1093/gerona/glw054 PMid:26984392 PMCid:PMC5106854 